\title{
A personal response to: The Woman Who Walked Into Doors by Roddy Doyle
}

Ann Jay General Practitioner, Llandysul, Ceredigion, Wales

Paula Spencer, nee O'Leary, is 37 years old. She looks much older, although she might have been good-looking once. The booze and the fags have taken their toll. She has four children, one of whom is an addict. They have not been well fed, probably because the money goes on vodka, and they've all been bed wetters. She was married to a small time crook who managed to get himself killed by the Garda during a bungled robbery. $\mathrm{He}$ was a charmer, though, and handsome, always very concerned about her when she had yet another fall under the influence. He would take her to the hospital and stay with her whilst she was treated.

Paula has a thick medical record. It bulges with reports from casualty about her black eyes and broken bones. She has been to her general practitioner on numerous occasions with complaints of tiredness and depression. She has never heeded the advice to cut down on her drinking and give up smoking, even when pregnant. She's on Valium most of the time.

"The doctor never looked at me. He studied parts of me but he never saw all of me. He never looked at my eyes. Drink, he said to himself. I could see his nose moving, taking in the smell, deciding."

Doctors don't like Paula very much. She could be described as a "heartsink" patient which probably amounts to the same thing. She doesn't like them either. They have singularly failed to help her. This is put another way in a paper by Butler and Evans:

“'Heartsink' and related terms like 'black holes', 'difficult', 'hateful' and 'health care abuser' are pejorative and it has been suggested that doctors use them to make themselves feel better at not being able to alleviate the multifaceted suffering of these patients." 3

Paula is, of course, a fiction, a product of Roddy Doyle's imagination, but such a rich and rounded product that I find it easy to think of her as a patient. Indeed she is so well written that it is actually quite difficult not to regard her as real. Most general practitioners know a Paula. They will meet her in the surgery and perhaps at a case conference. What they are much less likely to do is meet her at a party or as a neighbour. If they saw her in Tesco they would probably find themselves hoping she hadn't seen them.

Roddy Doyle introduces us to her in all her complexity. Through him she tells her life story. We meet the young, pretty girl who "swooned the first time" she saw Charlo, the man she married and we get the measure of the enormous sexual attraction between them. In the book two narratives are woven together, the happy story of Paula's life and the unhappy one. There is the story of the girl who spends most of her honeymoon in bed having a great time with Charlo, conceiving their first child, and the woman who is repeatedly beaten up and cowed by him. The bruises and broken bones, as we might readily guess, are the result, not of accidents, but of marital violence and Charlo takes her to the hospital, not out of concern for her, but to make sure she doesn't tell.

She doesn't tell and the medical staff don't ask although she prays that they will:

"Ask me.

In the hospital.

Please, ask me.

In the clinic.

In the church.

Ask me ask me ask me. Broken nose, loose teeth, cracked ribs. Ask me."

Recent research shows that unless battered women are asked in a direct and supportive fashion about the violence they still may remain silent. ${ }^{5}$ Why didn't they ask? Were they too busy or unaware or is it something more sinister than that? Paula Spencer was in no doubt: "It was my little secret and they all helped me keep it". ${ }^{6}$ 
Feminists, notably Ehrenreich and English, ${ }^{7}$ have long accused the medical profession of colluding in women's oppression. Illich suggests that the health professions rob people of the potential "to deal with their human weakness, vulnerability and uniqueness in a personal and autonomous way". It is perhaps less controversial to suggest that medicine, as a product of a particular society, will reflect the mores of that society. In Dublin in the 1970 s, where this story is set, unhappy women would have been unlikely to receive the help and support they needed to challenge the circumstances that made them unhappy. It is far more likely that they would have been encouraged to cope with an unsatisfactory situation by the prescription of a tranquilliser. ${ }^{9}$ In the 1970 s women were prescribed tranquillisers twice as often as men. Most advertisements for them featured women, often depicted as depressed housewives. Things have moved on since then Doctors are now taught communication skills and our awareness of abuse is more acute. We no longer regard benzodiazepines as a panacea for all ills.

But difficult social problems presenting under the guise of illness are still very much a part of everyday general practice. How do we avoid the "heartsink", the frustration at patients' failure to heed our advice about drinking and smoking, our incredulity at their inability to leave an abusive situation? One way is to understand them better. As Iona Heath says:

"Almost always, when I get stuck with a patient, when it begins to seem as if we are going round and round in circles, it turns out to be due to a failure of my imagination. The solution comes in seeking more detail, however small, of the reality of the patient's life. Each detail triggers new scope for the imagination, a renewed possibility of empathy and a much increased chance of the patient being heard."10

One way we, as doctors, can feed our imaginations is by reading fiction. When we see our "Paulas" in the surgery we are constrained by lack of time and all the paraphernalia of our medical training, both of which encourage us to look for proper diagnoses and cures. When we read a novel we engage with the character in a different way. We can perhaps get under their skin and more fully realise how for some people "cigarettes are sexythey're worth the stench and the cancer", ${ }^{11}$ as Paula Spencer says. Reading The Woman Who Walked Into Doors, we are reminded not only of the power of cigarettes, but of the power of love and lust, the forces that much health education breaks its back over. And we see why it took Paula seventeen years to leave Charlo. It isn't just concern for her children, or the lack of money, support and somewhere to go, although these things matter very much. It is also that she carries on loving Charlo, she carries on having the two strands to her narrative that Roddy Doyle makes us see. Leaving Charlo means abandoning the happy narrative, false though it seems to us, and admitting that the unhappy one is the real story of her life. To give real help to people like Paula we must not just ask the right questions when they present with a "peri-orbital haematoma" but also give them a way to rebuild a satisfactory narrative to their life.

Roddy Doyle's The Woman Who Walked Into Doors is a marvellous book. Reading it enables us to identify with a downtrodden, abused cleaner from Dublin and to appreciate the courage that makes her, as he does, a heroine. We see doctors and nurses through her eyes. It is a book that should be read by doctors and nurses everywhere.

Ann fay, MRCGP, DCH, DipPalMed, is a General Practitioner at Meddygfa Teifi Surgery, Llandysul, Ceredigion, SA44 4QF.

\section{References and notes}

1 Doyle R. The woman who walked into doors. London: Vintage, 1998.

2 See reference 1:23.

3 Butler C, Evans M. The "heartsink" patient revisited. British fournal of General Practice 1999;49:230-3.

Fournal of General Practi

4 See reference 1:187. physician. Fournal of the American Osteopathic Association [supp]. 1998;98, 12.

6 See reference 1:188.

7 Ehrenreich B, English D. Complaints and disorders. The sexual politics of sickness. New York: The Feminist Press, 1973.

8 Illich I. Limits to medicine. Medical nemesis: the expropriation of health. London: Marion Boyars, 1976.

9 Hardey M. The social context of health. Buckingham: Open University Press, 1998.

10 Heath I. "Uncertain clarity": contradiction, meaning and hope. British fournal of General Practice 1999;49:651-7.

11 See reference 1:3. 